\title{
The Model Construction and Path Exploration of Ruling by Law
}

\author{
Xuanming Zhang \\ School of International Studies, Renmin University of China, Beijing 100872, China \\ Email: 453515894@qq.com
}

\begin{abstract}
From the time when it came to power, the Chinese Communist Party's mode of governance has shifted from "ruling according to policies" to "ruling according to law." Domestic scholars have done a lot of discussion on the basic connotation and related concepts of governing by law. Most of these theoretical discussions are static and are an analysis and explanation of the actual situation. The Communist Party's ruling turn is an inevitable choice of regularity within the ruling logic, and more of a dynamic choice. The study of the logic of governing by law can more clearly discover the law of development followed by the Communist Party's way of governing. After this static analysis, the development route within the logic can be extracted. Combining the research results of academia, construct a dynamic mode of governing by law, find the subject, object and development path of governing by law, so as to clarify the reasonable boundary of civil rights, party power and political power, coordinate the development relationship among the masses, political parties and the state, and standardize The progressive process of the will of the people, the will of the party, and the will of the state.

Keywords: ruling party, logic, power, constitution and law
\end{abstract}

The Communist Party of China has always attached great importance to the construction of theory and practice of governing by law. President Xi Jinping attaches great importance to the construction of the theory and practice of "governance according to law". At the Fourth Plenary Session of the Eighteenth Central Committee of the Communist Party of China, the Party Central Committee made it clear that governing the country in accordance with the law in an all-round way, and included it in the "Four Comprehensives" strategic layout. The Fourth Plenary Session of the Nineteenth Central Committee of the Party put forward that the overall goal of comprehensively deepening reforms is to improve and develop the socialist system with Chinese characteristics and to promote the modernization of the national governance system and governance capabilities. It can be said that since the 18th National Congress of the Communist Party of China, the theoretical exploration and practical exploration of governing by law of the Communist Party of China have become increasingly mature. This article attempts to make a brief analysis and exploration of the connotation, mode, and path of governing by law.

\section{The connotation of governing by law: concept, foundation and logic}

\subsection{The concept of governing by law}

The generalization of the concept of governing by law is the prerequisite for constructing a model of governing by law. Since the founding of the People's Republic of China, although the Chinese Communist Party's governance style has undergone transformation, its fundamental governance content has remained unchanged. How to govern in accordance with the law is how to perform one's own governing content in accordance with the law. The essence of the party's governance is to govern for the people, and the party's concept of governance is determined according to this nature, and it is mainly divided into four parts.

First, select those in power and relevant officials who can be the masters of the people. Specific personnel recommendations must be approved by the National People's Congress. The Communist Party is the most critical party, and all work in China is carried out under its guidance. At the same time, the important and core leaders of our country are all born among the Communist Party members. In 1954, the first National People's Congress was held. After this meeting, my country's first leadership team was established. Through the convening of the people's assembly, the appointment of government officials in our country has gradually evolved to regularization and legalization.

Second, in the process of policy planning and formulation by relevant management departments, better play the leading role of the party. Various policies and strategies require the Communist Party to rely on relevant programs and documents. These policies must be able to coordinate and match the program. Conversely, the relevant documents and programs of the Communist Party have been implemented through these specific policies and strategies. The party no longer always interferes in the relevant work of the government, but only controls the overall situation. ${ }^{[1]}$

Third, the party is in charge of cadres. At this stage, there are a lot of talented civil servants in China, and the team is 
also very strong. The Communist Party pays special attention to the growth of this team and selects qualified cadres from it. However, channels, selections, activities, etc. are all transparent and compliant with the law. According to the current rules and strategies, it is necessary to always adhere to the principles of party management and leadership.

\subsection{The basis of governing by law}

The political basis of governing by law: the nature of the Communist Party. The Chinese Communist Party has always pursued that the people are the masters of the country. Governing in accordance with the law is to put the people in the first place and take the realization of their interests as the foundation of doing things. "The Constitution of the Communist Party of China" states: "The party not only represents the proletariat, but also represents the laboring masses of the country. It follows the mass line and can comprehensively promote and drive the development of the country's economy, and comprehensively improve the quality of life of the people. Work is carried out around the people." ${ }^{[2]}$ Only in this way can the people truly control the power, stay with the people, and always work for the people's welfare. At the same time, we must coordinate and take into account the will of the people in all fields, so that the interests of all the people of our country can be realized, and the pace of our country's common prosperity will be accelerated. ${ }^{[3]}$

The theoretical basis for governing by law: the party in power has clearly defined its powers. In modern society, the foundation of the country's stability lies in the unity of party power, political power (not the so-called national sovereignty, but public power) and civil rights, and at the same time, it must be based on the law. Civil rights are the so-called rights of the masses. Sovereignty among the people has always been the foundation of the Communist Party of China. Party power can be divided into broad and narrow sense. Broadly speaking, party power represents two aspects. First, the party has its own influence in society; second, the party's control over the political power. In a narrow sense, party power only refers to the second aspect. Political power represents a collection of various horizontal and vertical powers. Horizontal power involves a lot of content, such as legislative power, administrative power, and so on. These horizontal powers are the main content of our country's regime. We must define the boundaries of these three powers in accordance with laws and regulations.

The practical basis of governing by law: the protection of human rights. The human rights here refer to the basic rights that people have in carrying out various social activities derived from their own survival and development in a specific environment. It includes the right to subsistence, personal rights, and political rights. For an individual, human rights cannot be ignored. This requires us to respect and protect these human rights. Human rights must be put in the first place in the process of implementing various powers of the country. The existence of human rights keeps the country in a good state of operation and will not transform into dictatorship and tyranny. ${ }^{[4]}$ The ruling party has a very strong ruling power, not only to respond to the society, but also to control the society to a certain extent. ${ }^{[5]}$ Governing in accordance with the law requires the Communist Party to respect human rights as a prerequisite and leave enough space to protect the basic rights and freedom of citizens.

\subsection{The logic of governing by law}

The logic of governing by law has four basic contents, namely the core, the subject, the object, and the path. The core of governing by law is the constitution and laws. Only by guaranteeing the spirit and authority of the Constitution can we truly govern in accordance with the law. The main body governing according to law is China's only ruling party-the Communist Party of China. The party's rule by law is "the party implements leadership through the state power and the laws expressed by the will of the country." [7] Governing by law is to ensure that the people are the masters of the country, so the direct object of governing by law can be regarded as a state institution. Therefore, its fundamental object is the country and the people. The path is divided into two parts: the social system and the political system, which can be realized mainly from the two aspects of political parties formulating and implementing the constitution. The logical relationship of these four parts is shown in Figure 1.

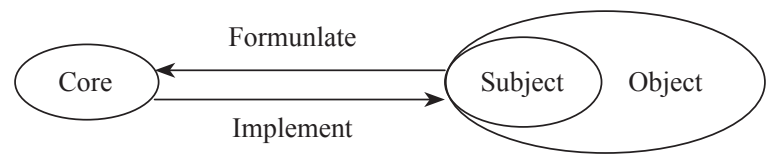

Figure 1. The logical relationship of governing by law

What needs to be further explained is the unification of subject and object. On the one hand, the object can be the fundamental object, that is, the people. The subject is in the object. As the main body of the ruling party, the Communist Party, originated from the masses, based on the masses, representing the will of the masses, and was widely supported and trusted by the masses. Therefore, the party's rule by law means that a value orientation is established in the object, and the 
masses will spontaneously move closer to the constitution and laws. This forms an order in the social system. This order forms an external environment for the ruling party to effectively govern in accordance with the law, which in turn promotes the Communist Party's behavior in governing in accordance with the law. In the final analysis, this result is that the subject derives from the object and represents the object. However, for the sake of logical rigor, the ruling party has a legitimacy foundation that has become a major premise for the party to represent the people. "The ability to mobilize is the unique advantage of the Chinese Communist Party...The continuity of ideology is also regarded as one of the important sources of legitimacy." [7] It can be seen that this major premise is certain and stable. .

The object, on the other hand, can be a direct object, that is, a national institution. The subject is above the object. The previous article pointed out that the Communist Party as the main body should recommend and appoint important leaders, and enter the political system as a representative of the ruling party. The real ruler of the country (in a narrow sense) is the representative of the ruling party, "the first bearer of the ruling responsibility" ${ }^{[8]}$, and is directly responsible to the party. Then the way the party governs in accordance with the law, coupled with its own authoritative influence, directly transfers the appointment and management of cadres from top to bottom, and is standardized step by step. In the political system, an internal environment that guarantees governance according to law has gradually formed, so that the party's governance according to law can be implemented. The subject is higher than the object, and the object is regulated. The logical premise needed here is to ensure institutional construction and ensure that under the leadership of the party, the system can effectively regulate the governing behavior of cadres and officials.

Taken together from the two aspects, the subject of governing according to law is not only derived from the object, but also higher than the object. In order to be able to construct a highly concise, full-content model, it is theoretically possible and necessary to unite subject and object. The prerequisites for the unity of subject and object at the two levels are legal foundation and institutional construction respectively. The key condition for the effectiveness of these two premises depends on the core of governing according to law-the constitution and law. From the legal level, the Constitution endows political parties with a foundation of legitimacy, as well as legal support for institutional construction. Therefore, it is logically feasible to unite subject and object. Figure 1 can be simplified to Figure 2 (how the path goes from the start to the end. In the rule of law, it is how to go from the subject to the object, and the unity of the subject and the object makes the path blend into the side of the subject).

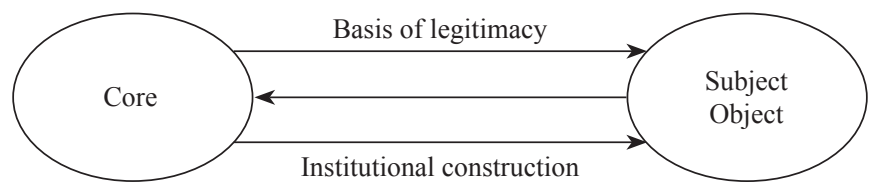

Figure 2. The unity of subject and object governed by law

\section{Model construction of governing by law: subject, power and path induction}

After the logical simplification of the model of governing by law, the next step is to enrich the content of the logic and construct a model of governing by law. This model must not only reflect the core status of the constitution, but also reflect the leadership of the party. It is necessary to unify the subject and object, but also to unify the path. Among the four elements, the core, subject and object have been briefly analyzed, and the path of governing by law is the focus of the analysis. The path refers to the progress in the social system and the political system, in which the legislature improves the legislative system. The party must play a proactive and leading role in the formulation and implementation of specific laws. When formulating relevant laws and regulations, we must strictly refer to the Constitution. If you need to make adjustments to specific norms and systems, you need to report to the government management department in a timely manner, and make further instructions through the National People's Congress. At the same time, the corresponding National People's Congress and the Standing Committee of the National People's Congress shall be set up to carry out the formulation and implementation of laws and regulations and the management and repair. Moreover, in order to better manage laws, regulations and institutional systems, it is necessary to establish a normative system for the management of laws and regulations.

Administrative agencies must play the role of government in accordance with laws and regulations, and make timely and comprehensive improvements and adjustments to the existing administrative departments and the administrative process regulation system. While performing its basic functions and functions in an all-round way, the administrative department must take the lead, resolutely safeguard the legal system, and impose strict penalties on those who violate the law or dereliction of duty. In addition, the administrative department must have a clear understanding of the scope of its own powers, and should not abuse its powers to harm the interests of others. In order to make the decisions made by the management departments more scientific and reasonable, and to comply with relevant regulations and standards, it is necessary to gradually establish 
an operating mechanism to act in accordance with the law, so that the conduct of various tasks can obtain more legal norms and basis. When formulating and implementing laws and regulations, more public opinion must be solicited to make the formulation and implementation of laws and regulations more scientific and reasonable. When the administrative department makes major decisions, it is necessary to gradually form a relevant decision-making review management system to ensure the legitimacy of the decision-making.

When building the legal system, it is necessary to further enhance people's awareness of the legal system. Through comprehensive legal education to the general public, people gain an in-depth understanding of the legal system. On this basis, let people learn to use the law as an important tool for safeguarding their basic rights and interests, so that people can solve many problems through the help of the law. In addition, all party and government leaders must take the lead in promoting people to strictly abide by laws and regulations. On the one hand, party and government personnel must do a good job of daily work and strengthen publicity and education of the legal system. On the other hand, party and government personnel must obey the leadership of the organization and complete the instructions of their superiors in a timely and serious manner. In order to better exert the basic functions and effects of the legal system, it is also necessary to gradually establish a scientific and reasonable legal system operation and management system based on the actual situation, so that people can more conveniently maintain their own rights and interests through the help of the law. Moreover, it is necessary to further establish a legal aid operation mechanism, so that those who do not understand the law can be protected by the law and increase people's recognition of the law. The above is the necessary path to achieve governance in accordance with the law in the social system.

After enriching the content of the path, the overall mode of governing by law can be constructed, as shown in Figure 3.

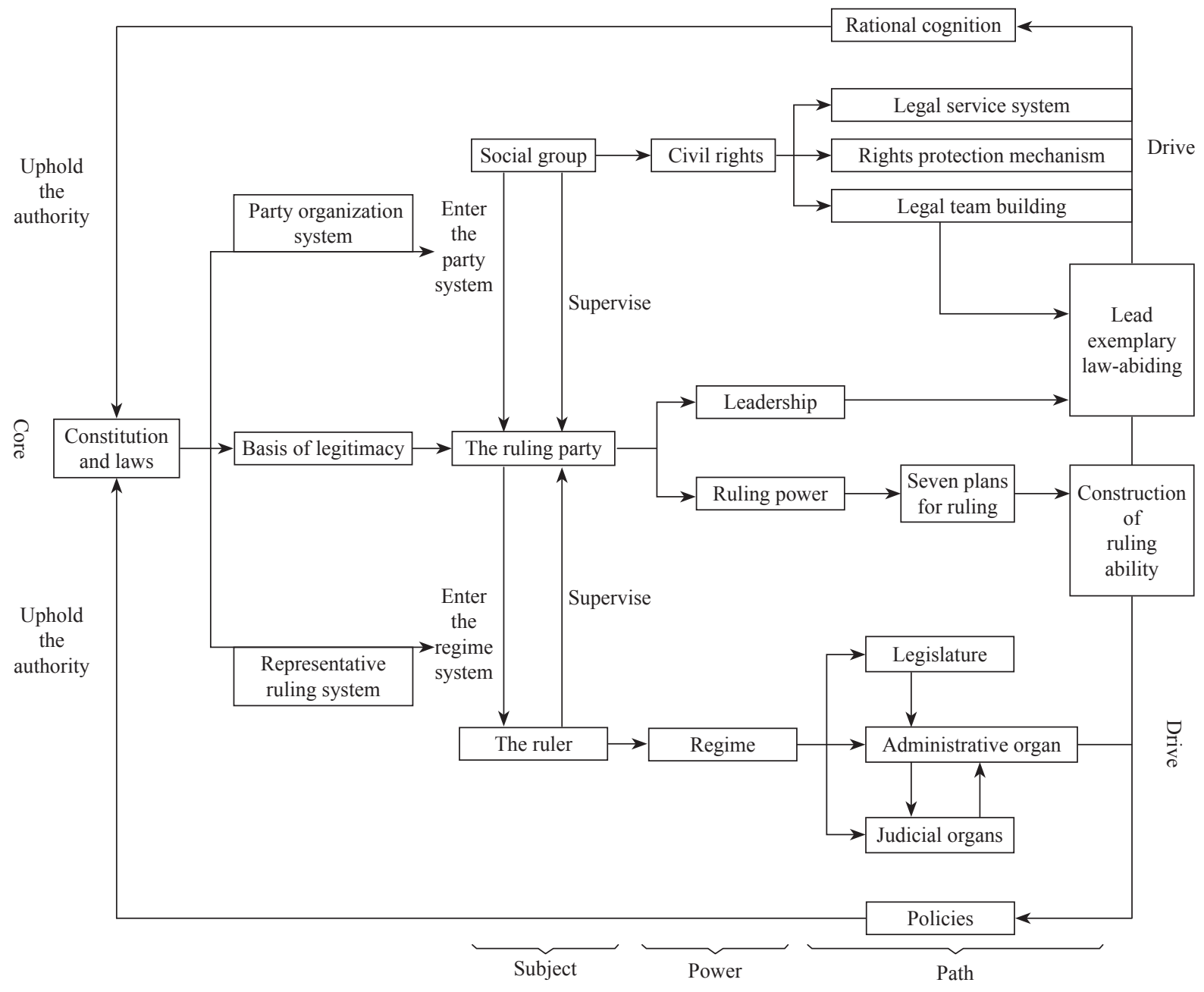

Figure 3. The model of governing by law 
In this model, the ruling party is given a legal basis by the constitution. The system of representative governance and party organization guaranteed by the constitution regulates the transition from the masses to the ruling party, from the ruling party to the ruling party, and realizes the legitimacy of the subject and object of governing in accordance with the law. The leadership, governing power, civil rights and political power exercised by the subject and object themselves also have subjective norms. The creation of the main body and the governor according to the law and the system is also the first step to put power in the system cage.

When the ruling party formulates policies in accordance with the law, the legal process model is shown in Figure 3 . The main process is still in the political system. Only those powers that come from the people and are supervised and restricted by the people are called public powers. ${ }^{[9]}$ Therefore, the ruling party must first listen to the opinions of the masses, gather policies to collectively embody the will of the masses, and then transfer them to the ruling party to form the will of the party. The ruling party submits it to the legislature of the National People's Congress and the CPPCC. The National People's Congress passes it through to the administrative agency and other relevant functional departments, and then the administrative agency to the judiciary. Finally, after deliberations, the administrative agency implements the will of the country and safeguards the will of the masses. In the social system, the ruling party must establish a value orientation to allow the masses to consciously move closer to the constitution and laws. Therefore, in the social system, the ruling party endows the people with legal awareness and legal authority. On this basis, the masses used civil power to establish their own legal service system, rights protection mechanism, and team of lawyers. In the system of safeguarding the interests of the masses, the public power in the regime is only an intermediary, in order to allow the masses to better exercise their civil rights.

It is a common phenomenon for political parties to run political power. ${ }^{[10]}$ In the mode of governing by law with the party as the main body, the constitution is the core of this mode. The direct output of the constitution is the party organization system and the representative governance system. The subject must strictly abide by these two systems and enter the social and political system in the process of governing, in order to achieve the most basic governing by law. On this basis, some specific implementation methods and guarantee methods are needed to achieve true governance in accordance with the law. The result in the two systems is that the level of governance capacity building is improved, and the exemplary and leading role of compliance with the constitution and laws is fully brought into play. As the authoritative input of the constitution, these two can further clarify the core status of the constitution and guarantee the implementation of the mode of governing by law. In the mode of governing by law based on the constitution and law, the ultimate goal is to improve the party's governing ability and leadership. This is also the reason why the party's governing method has transformed to governing by law. The party is able to govern in accordance with the law and maintain the authority of the constitution, and it is also able to maintain its own authority (leadership and power). And the constitution can guarantee the authority of the party, so in the mode of governing by law, the party and the constitution and laws are also unified. Under this model, the party and the masses, the party and the cadres, and the party and the constitution and laws can all be unified. This is even more a highly manifestation of the party's leadership. Therefore, governing by law is the inevitable choice of the Communist Party's way of governing.

\section{Exploring the path of governing according to law: system, party building, constitution and law}

As mentioned above, abiding by the two systems in governing by law is only a basis for realizing the mode of governing by law. To truly realize governing by law requires certain channels and guarantees, and these channels must be both specific and general. According to Figure 3, the logical elements of governing by law are used as the standard for analyzing the ways to achieve governing by law. This article analyzes the way to govern by law from three aspects: the power, subject and core of governing by law.

\subsection{The choice of power system}

After the two systems exported by the constitution are fully complied with, there is still a link between the two from the main ruling party to the final path-power. It affects whether the ruling party can be closely linked with the political system and the social system. On the one hand, we must be able to keep power under the control of the system. On the other hand, we must be able to let go of power and no longer let it be constrained all the time. To release the cage means that the people can supervise state power and so on. Let the people's power be released, and the government will be restrained. This is the institutional norms of power. The choice of this system is for a better interaction between political power and civil rights. Fundamentally speaking, the Constitution is used to control state power and respect the power of the people. From this perspective, the Constitution also has provisions related to the obligations of the people. Generally, there is no way in the constitution to stipulate the obligations of the people. The constitution was formulated to respect the rights of the people. 
Now suddenly there are more obligations, which seems a bit abrupt. Although it is a cumbersome at present, it is not meant to be corrected immediately. In the analysis, we must know the relationship between state power and legal order, and grasp the relationship between the two levels. First of all, we must control the implementation of state power under a stable legal order so that it will not act recklessly. Secondly, people's power is inherent and not granted by the state. Therefore, the state department cannot be superior, thinking that respect for power is a kind of favor. In fact, power is also given by the people, and the people can exercise supervision and restraint on state power.

\subsection{Construction of party regulations and laws within the party}

The ruling party is the main body governing in accordance with the law, and is the key to preventing the deterioration of the constitution and laws. The "boosting agent" for activating the constitution and laws is the party regulations and laws within the party. Discipline within the party originates from the national law, but it is higher than the national law, and it will also be transformed into the national law. The completeness of the party's laws and regulations is an important indicator of the maturity of the party's development and an important basis for the party's ideals to be transformed into the constitutional spirit.

In May 2013, the Communist Party of China publicly issued the "Regulations on the Formulation of Inner-Party Laws and Regulations of the Communist Party of China" and revised the "Interim Regulations on the Procedures for the Formulation of Inner-Party Regulations of the Communist Party of China" issued in 1990. The promulgation of these laws and regulations is a manifestation of my country's party building measures becoming more and more regular, and it is also the key to my country's adherence to scientific and democratic governance. ${ }^{[1]}$ The construction of party regulations and laws can enable the party to better abide by and maintain the constitution and. While governing in accordance with the Constitution, it is also necessary to formulate internal party laws and regulations to govern the party. Moreover, the study of party regulations and laws can improve party members' understanding of party regulations and party laws, so that they can better carry out various party affairs according to their basic requirements. The study of party regulations and laws enables party members to learn from role models and improve their abilities. Therefore, the improvement and perfection of party regulations and laws can further enhance the authority of the law.

\subsection{Perfect Constitution and Law}

The constitution is the core of governing by law. If you want to govern by law, you must have good laws. This political prerequisite must be determined so that good governance can be established on the basis of good laws. Therefore, the constitution must be a good law that conforms to the national conditions, reality, and the development requirements of the times, reflects the common will of the people, safeguards the fundamental interests of the people, and protects the people's democratic rights. ${ }^{[12]}$

Good law is essentially a universal and just law that can be universally recognized by most people and can establish a universal belief in the constitution among the people. This kind of rational collection allows the people to abide by it unanimously. This is a universal force for the implementation of governing by law, and it plays an important role. To formulate a good law, the following must be done. First of all, when electing legislative organizations, the role of the people must be brought into play so that they can participate autonomously and regularly. Only in this way can the law reflect the wishes of the people. Second, learn from the experience of other countries. The constitutional court can be set up appropriately, and it can perform review and other tasks, depending on whether the relevant laws are reasonable. If it does not comply with the constitutional provisions, it can be declared directly ineffective to ensure the usefulness and goodness of the law. ${ }^{[13]}$ Again, it is necessary to be able to effectively implement the utility of freedom of public opinion. Through public opinion, phenomena and conditions in society can be fed back to relevant agencies, and the actions and actions of legislators will also be supervised by public opinion. The people can express their feelings and put forward their own suggestions to ensure the fairness of the law.

\section{Conclusion}

From the will of the people, the will of the party, and the will of the state expressed by the masses, the political party, and the state, to the civil rights, party power, and political power derived from them, it is an intricate transformation process. The evolution of this process needs to go through a legalization path, so that the will of each link can be truly expressed, and the power of each link can be truly exercised. In the mode of governing by law, the subject and the object are bones, the revealed will is the meridian, and the specific operation of power is the circulating blood. Only by confining power to the cage of the system and giving full play to civil rights can the mode of governing according to law function in flesh and blood. The legalized governance model is not only the only way for our country's political parties to govern, but also the 
inevitable choice of other countries' political parties. The legislative and constitutional measures of political parties in the United States, Germany and other countries are concrete manifestations of governing in accordance with the law.

\section{References}

[1] Li Jingzhi. Comparison of the ruling styles of the Chinese and Western ruling parties and their enlightenment. Journal of Renmin University of China. 2005; (5): 81.

[2] Questions and Answers on the Study of the New Party Constitution. CPC Central Party School Press; 2002.

[3] The Tutoring Reader of the 16th National Congress of the Communist Party of China. People's Publishing House; 2002.

[4] Zhang Wenxian. Jurisprudence. Higher Education Press, Peking University Press; 1999.

[5] David Miller, et al. Blackwell Encyclopedia of Political Science. China University of Political Science and Law Press; 1992.

[6] Shi Taifeng. Zhang Hengshan. On the Chinese Communist Party’s Rule by Law. Chinese Social Sciences. 2003 ; (1): 15.

[7] Wang Changjiang. 2014 Annual Report on the Construction of the Ruling Party. Jiangsu People's Publishing House; 2014.

[8] Shi Wenlong. Research on the institutional construction of governing by law. China Social Sciences Press; 2013.

[9] Yang Siji. An analysis of public power and private rights and their conditions-also on China's political system reform. Journal of China University of Mining and Technology. 2013; (2): 15.

[10] Xi Fuqun. Service-oriented ruling party and its construction path analysis. Journal of China University of Mining and Technology. 2015; (2): 5.

[11] Zhen Xiaoying. The first "Intra-Party Legislation Law" to promote the construction of the ruling party system. Frontline. 2013; (7): 53.

[12] Zhuo Zeyuan. The long-term goal of 2035 and the construction of a rule of law in a country ruled by law, a government ruled by law, a society ruled by law. People's Forum.Academic Frontiers. 2021; (03): 4-8.

[13] $\mathrm{Hu}$ Wei. Insisting on scientific governance, democratic governance, and governance according to law-and on the construction of socialist democracy in my country. Theory and Reform. 2020; (02): 150-159. 